\title{
THE COMPENSATION AND BENEFITS SYSTEM: PRIVATE COMPANIES vs. BUDGETARY SYSTEM
}

\author{
Bogdan ALDEA \\ West University of Timişoara \\ (C) 2015 Bogdan Aldea \\ This is an open access article distributed under the Creative Commons Attribution-NonCommercial-NoDerivs license \\ (http://creativecommons.org/licenses/by-nc-nd/3.0/) \\ DOI: $10.1515 /$ eras-2015-0009
}

\begin{abstract}
The economic evolution of the last decades has entailed major changes concerning the Human Resource Management practices, in both private and budgetary sector of Romania. In order to maintain efficiency and market competitivity, a company must adapt to these changes by altering its human resource strategy since managers are encountering increasingly complex challenges as to attracting, motivating and retaining employees. Such an objective might be accomplished by elaborating a competitive system of employee compensation. This article focuses on the stage reached by the Human Resource Management in the compensation and benefits system of the private and budgetary sector. For the latter, we are focusing on the romanian system of higher education. This study demonstrates that the compensation and benefits system which is implemented in romanian universities is limited and can offer few opportunities as compared to the one implemented by private companies. It is worth saying that the legal system has a negative impact in this matter.
\end{abstract}

Keywords: Human Resources, Compensation and Benefits, Motivation, Performances

\section{Introduction}

The present system is defined by an increased dynamics of the human resource. The human resource is the most important asset of an organization. Attracting and retaining the competent human resource is a main objective for any organization, whether it is in the private or public sector. Thus, the compensation and benefits package represent a convergent point regarding interests of employees and employers. Rewarding personnel loyalty through various reward strategies is a highly important aspect in an organization's Human Resource strategy. Even if apparently, extra wage compensations and benefits represent further costs for the employers, should we consider the advantages that this strategy entails in the loyalty program, then these costs are assumed.

Transposing the business strategy of every company in its Human Resource strategy (regarding employee retention, recruitment, increasing employee performance through motivation) is an onset in elaborating a compensation and benefits system. The company's performance and life span depend on the ability with which this system is conceived. The type of compensation differs, depending on the content, volume or the conditions in which it is implemented, as different contexts may be encountered. Obviously, the result is obtained only if the entitled authority manages to identify the optimal forms of compensation.

Even if currently, the base pay and the bonuses continue to remain the main elements of employee motivation, lately, a change of importance regarding the extra wage packages can be observed. This is extremely visible, especially in the private sector. Table 1 illustrates a short synthesis of the main extra wage motivational packages that are implemented in the East European countries. 
Table 1. Extra wage benefits in East - European countries

\begin{tabular}{|c|c|c|c|c|c|}
\hline Romania & Hungary & Poland & Ukraine & Czech Republic & Slovakia \\
\hline Meal vouchers & Meal vouchers & $\begin{array}{l}\text { Private } \\
\text { medical } \\
\text { services }\end{array}$ & Mobile phone & Meal vouchers & Meal Vouchers \\
\hline $\begin{array}{c}\text { Private medical } \\
\text { services }\end{array}$ & $\begin{array}{l}\text { "Szechenyi" } \\
\text { holiday card }\end{array}$ & Meal vouchers & $\begin{array}{l}\text { Presents for } \\
\text { the employees }\end{array}$ & Mobile phone & Mobile phone \\
\hline $\begin{array}{c}\text { Extra annual } \\
\text { leave }\end{array}$ & $\begin{array}{c}\text { Clearing } \\
\text { transport costs }\end{array}$ & $\begin{array}{c}\text { Sports } \\
\text { activities }\end{array}$ & $\begin{array}{l}\text { Training } \\
\text { programs }\end{array}$ & Laptop & $\begin{array}{l}\text { Flexible } \\
\text { schedule }\end{array}$ \\
\hline Mobile phone & $\begin{array}{l}\text { Grants for child } \\
\text { education }\end{array}$ & Car & $\begin{array}{c}\text { Clearing } \\
\text { transport costs }\end{array}$ & Training programs & Work at home \\
\hline $\begin{array}{l}\text { Team Building } \\
\text { programs }\end{array}$ & $\begin{array}{l}\text { Loans in } \\
\text { peferential terms }\end{array}$ & $\begin{array}{l}\text { Cultural } \\
\text { activities }\end{array}$ & Car & Private pension & $\begin{array}{c}\text { Team Building } \\
\text { programs }\end{array}$ \\
\hline Laptop & $\begin{array}{c}\text { Private medical } \\
\text { services }\end{array}$ & $\begin{array}{l}\text { Flexible } \\
\text { schedule }\end{array}$ & $\begin{array}{c}\text { Food } \\
\text { allowance }\end{array}$ & $\begin{array}{l}\text { Private life } \\
\text { insurance }\end{array}$ & $\begin{array}{l}\text { Training } \\
\text { programs }\end{array}$ \\
\hline $\begin{array}{l}\text { Clearing } \\
\text { transport costs }\end{array}$ & Private pension & $\begin{array}{l}\text { Training } \\
\text { programs }\end{array}$ & $\begin{array}{l}\text { Flexible } \\
\text { schedule }\end{array}$ & $\begin{array}{c}\text { Private medical } \\
\text { services }\end{array}$ & Laptop \\
\hline $\begin{array}{c}\text { Presents for } \\
\text { children (1st of } \\
\text { June, Christmas) }\end{array}$ & $\begin{array}{l}\text { Training } \\
\text { programs }\end{array}$ & $\begin{array}{l}\text { Private life } \\
\text { insurance }\end{array}$ & $\begin{array}{l}\text { Private } \\
\text { medical } \\
\text { services }\end{array}$ & $\begin{array}{l}\text { Sports / cultural } \\
\text { activities }\end{array}$ & Private pension \\
\hline
\end{tabular}

Source: http://www.wall-street.ro/articol/Careers/186926/beneficii-acordate-de-angajatorii-romani-comparativcu-practicile-din-regiune.html

Regardless of the type of benefits offered, one of the basic rules refers to calibrating them based on socio - demographic variables and especially type of organization. Thus, a compensation and benefits system ought to be flexible and oriented to market requirements in general and to those of employees in particular. Consequently, the major distinction is between the compensation and benefits system of the private companies as against that of public institutions.

In Romania, the systems of compensation and benefits which are implemented by private companies are evolving, being altered each year in structure (modification of component weight) and wage level, a level increased by an annual average of 5\% (Hay Group, Pricewaterhouse Coopers, AIMS).

Instead, the system of compensation and benefits which is implemented in the budgetary sector is in a great measure conceived and controlled by laws and methodologies of application that were designed based on the budgetary income and its use in some destinations. Depending on the state budget and the minimum wage level, the state adjusts through laws and emergency ordinances, the level of the wage in the budgetary sector, increasing or decreasing salaries when necessary. At the same time, the state controls through laws whether benefits (such as meal vouchers, holiday vouchers or the $13^{\text {th }}$ wage) are or are not given to employees. As a matter of 
fact, meal vouchers are most commonly present in the compensation and benefits packages that are given in public institutions. Graph 1 presents an estimation in the euro currency of the value the meal vouchers have had during 2015 in the East - European countries.

Graph 1. Estimation in the euro currency of meal vouchers value

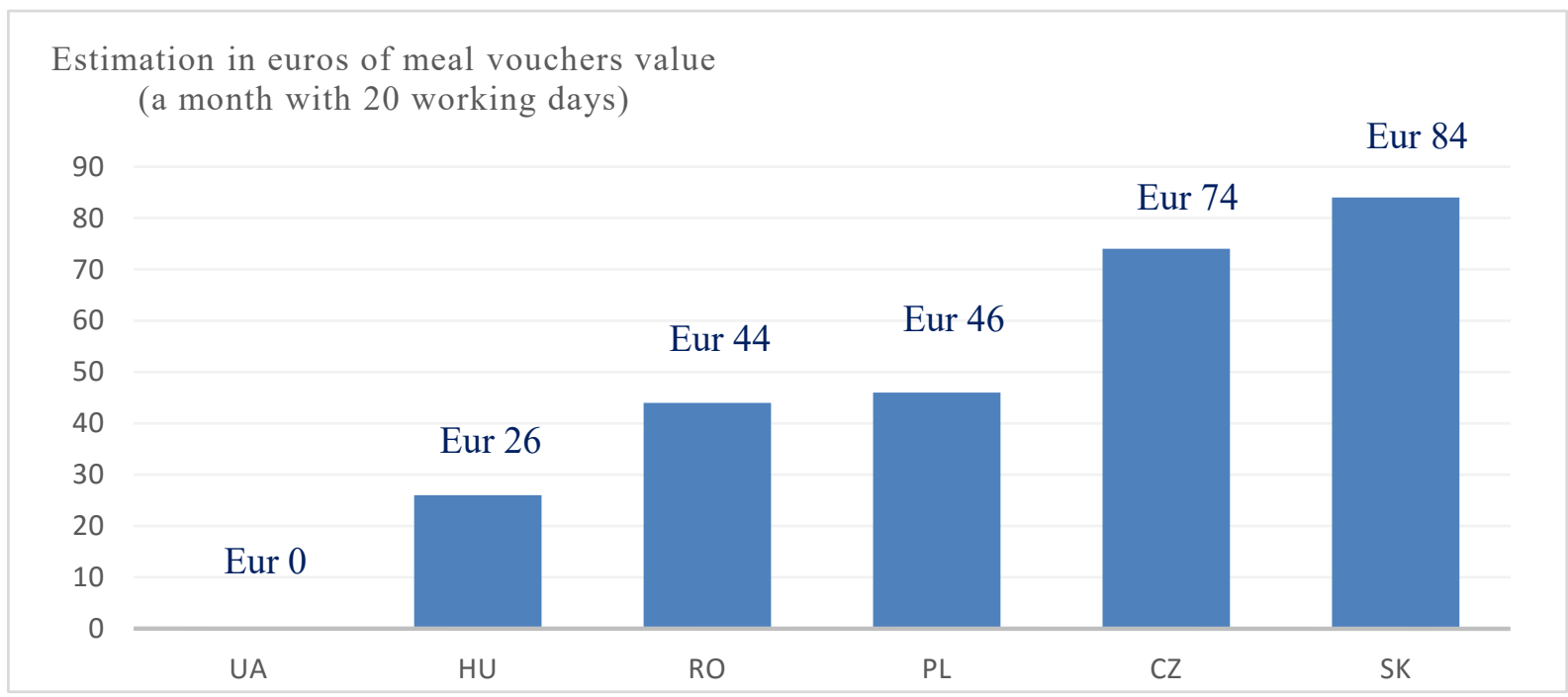

Source: EDENRED

Regardless of the sector in which it is implemented, the system of compensation and benefits must base itself on a personalized design, starting from the following aspects:

- Package customization

- Flexibility

- Criterion of performance

- Internal vs. external equity

- Structure

- Transparency

- Legal aspects

The objectives of this research were that of analyzing and amply comparing the system of compensation and benefits in the private and public sector of Romania, with an emphasis on the system that is implemented in the institutions of higher education. For the second dimension, a Romanian public university was taken as reference model.

The motivation of reducing the analysis of the aforementioned system to a sole university is based on the homogeneity of compensation policies clearly established by law. The onset premise was that we are dealing with a far more rigid system of compensation and benefits at the level of budgetary institutions. This aspect is determined by the wage policy that is being legally implemented in the entire country.

This analysis also offers recommendations for the decision-makers ahead of optimizing the public sector system of compensation and benefits, so that it could become more flexible and more performance oriented. 


\section{Literature review}

The role of compensation and benefits' package in the human resource policy of a company has been approached in numerous studies. The matter of emphasizing the relation between work performance and wage / extra wage benefits received by the employee has also been the object of several research endeavors. In his study, Lanzalotto (2007) was saying that the most important issue for the employers is that of succeeding in implicating employees in the company's idea of business, through creating a system of compensation and benefits desired by them. According to the same author, this would facilitate the retention of performing employees and intellectual property, a key element in increasing company performance and opportunity.

The socio - economic importance of compensation and benefits system on all levels of company functioning is perhaps described the best by M. Armstrong (2006): "A philosophy of rewards may reflect an existing organizational culture or may be employed as a factor of change". According to this logic of ideas, one of the frequent themes in profile studies has been the connection between employee performance and the existence of a coherent package of compensation and benefits (Banker et al., 2000). In fact, the evaluation of performances represents a basic activity of human management resources (Lefter et al., 2007).

At the same time, we must consider the aspects of social class determining different attitudes towards labor. A low skilled person requires a certain type of extra wage motivations, generally material ones, while for a high skilled employee, symbolic benefits are more important (Pânzaru, 2013). Consequently, the system of compensation and benefits must not be reduced to material aspects. Symbolic aspects must also be considered. Performance depends on the manner in which material and symbolic benefits are combined in the same way that economic development depends on the existence and quality of resources (human, natural, physical). Thus, the manner in which these resources are present, combined and coexisting confers a certain value and dimension to the socio - economic development (Pânzaru, 2012).

In this respect, a series of studies carried out by non-governmental or private organisations have to be mentioned. The motivation of such endeavours, less scientifical but with a considerable practical importance is given by the need of knowledge concerning the employees' level of performance inside public institutions. Performance is an essential part of the trust people confer to public institutions (UCRAP, 2007). From another perspective, the components of total compensation's policy, the manner of its communication, the legal requirements specific to each country, the perception of equity in each country and cultural compatibility have been analyzed in a study carried out by SHRM (2009).

\section{Methodology}

The system of compensation and benefits (also known as C\&B) represents a discipline of human resources which is focused on the policy of employee motivation through compensations and benefits. This discipline is known in the United States of America as "total compensations" or "remuneration" in Australia and New Zealand.

In the elaboration of such system of compensation and benefits, the following particularities are considered:

- Package customization: benefits must be customized according to each employee's will. A starting point in this matter is the real necessity of the employee. When the system is customized according to this criterion and, naturally, according to the allotted budget, both motivation and retention level increase.

- Flexibility: it implies a wide array of benefits, out of which the employee may chose, 
depending on the budget. Despite the fact that the administration of a wider array of benefits is more difficult, the employee can chose - in the limit of the budget - one or more benefits from the company's portfolio.

- Performance correlation: the system must be correlated with the company's performance, thus the amount of the performance bonus shall be proportional with the employee's performance.

- Internal vs. external equity: a properly built policy of compensations and benefits must consider and be correlated with the offer of the market where the company exists, thus sustaining the process of recruitment and selection.

- Structure: this implies: 1) the stable part which includes the base pay and other benefits such as the one for years of service, the one for night work, etc, allowances; and 2) the irregular part which includes the performance bonus, the holiday bonus, sales commissions, the 13th salary, bonuses according to employee needs, employers' objective and available budget. In the determination of the bonusing system, three objectives are being considered:

○ Employee performance. The employee must realize that the bonus he shall receive depends on his individual performance and on the manner in which he accomplishes the objectives defined by the employer, the purpose of the bonus being that of creating a stimulant in order to improve performance.

- The cost of labor force vs. the company's financial results. The budget allocated to bonuses is annually adjusted, according to financial results, thus the cost of labor force being automatically reduced in less favorable or crisis moments for the company, whereas, during prosperous periods, the fund allocated to bonuses is being increased.

- Employee retention. The retention of employees is not considered a main objective of the bonusing system, but it also has to be considered likewise. For example, shall the bonus be given on an annual basis, the employee will be less tempted to leave the company before bonus payment. It is thought that the employer will gain time for the company, by retaining the employee.

- Transparency: the system of compensation and benefits, as well as the grounds on which it has been elaborated ought to be clearly communicated to employees. Employees must understand the manner in which they are remunerated and the existing link between the system and individual and company performance.

- Legal aspects: when conceiving a system of compensation and benefits, the company must also consider the legal system, the possibilities and the facilities it offers. Starting from the limitation of the budget allocated to the package of compensation and benefits, a company ought to recognize and maximize the fiscal facilities the legal system offers through managing certain benefits as deductible expenditures, private pensions or holiday vouchers.

The present research has been an exploratory - descriptive research of analysis and evaluation on comparative terms of the system of compensation and benefits implemented in the private and public sector. The approach was based on the following framework of the compensation and benefits system: 
Table 2. The structure of the system of compensation and benefits

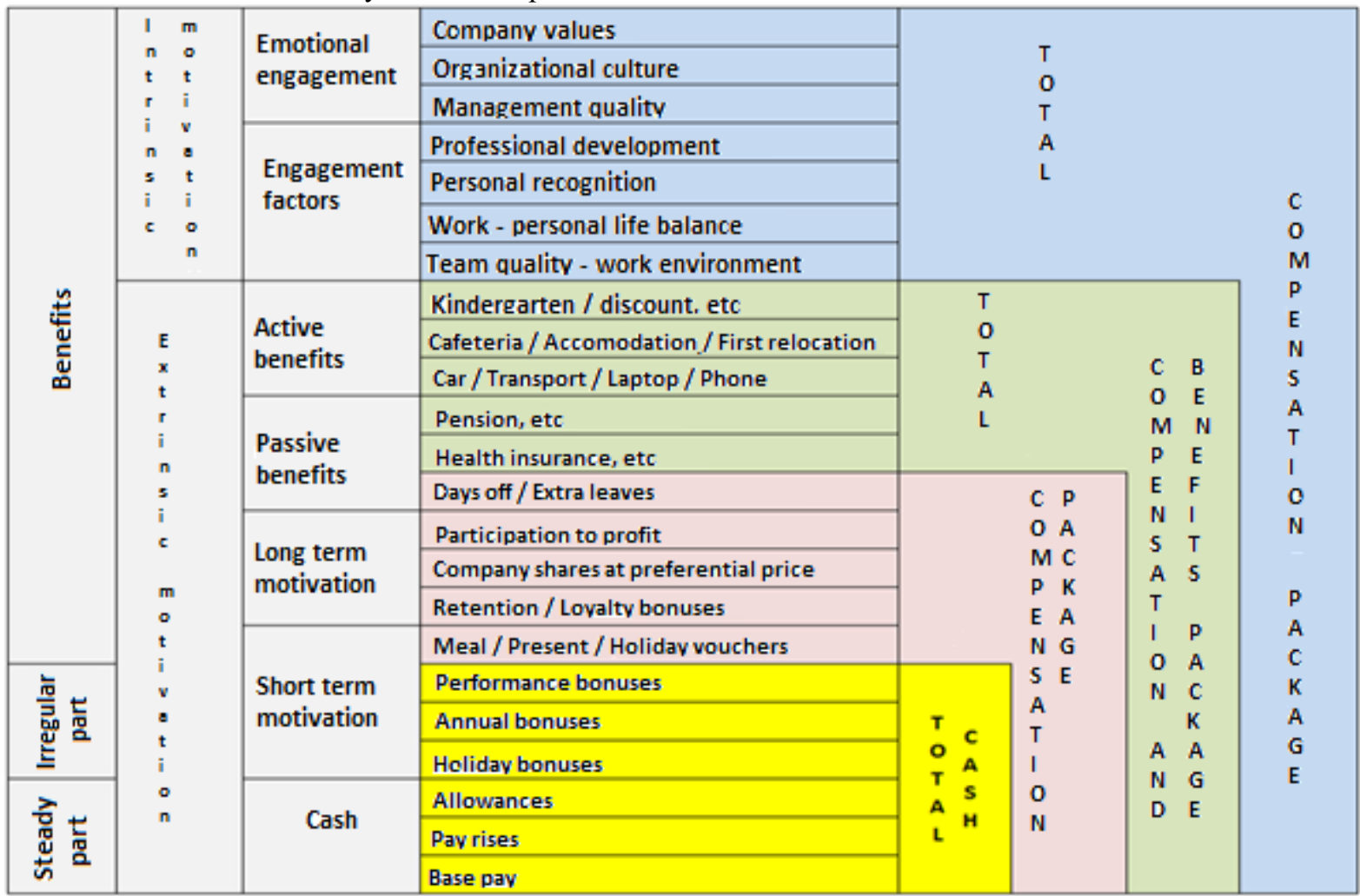

Source: own elaboration

Starting from the structure of a compensation and benefits system illustrated in table 2, as well as from the legal framework which controls the public sector, the analysis focused on the evaluation of possibilities regarding employee motivation, especially their retention, the degree of flexibility and innovation.

\section{Results}

According to a study carried out by Pricewaterhouse Coopers (Graph 2), the packages of compensation and benefits are being altered each year, the rate of bonuses and extra wage benefits increasing, as against the system which is implemented in the budgetary sector, where the structure of the aforementioned system remains unaltered. Moreover, the base pay is having an increased rate.

Thus, in 2015, by means of the regulations of the Emergency ordinance nr. 83/2014, modified by the Emergency ordinance $\mathrm{nr}$. $54 / 2015$, the base pay in the public sector, especially in education, have been increased with 26.8\% (5\% from March, 5\% from September, $12 \%$ from December). At the same time, benefits and bonuses regulated by law, as meal vouchers, holiday vouchers, the 13th salary ore extra hours being suspended from the beginning of 2009 . 
Graph 2: Structure of wage package - general market (\% of the wage package)

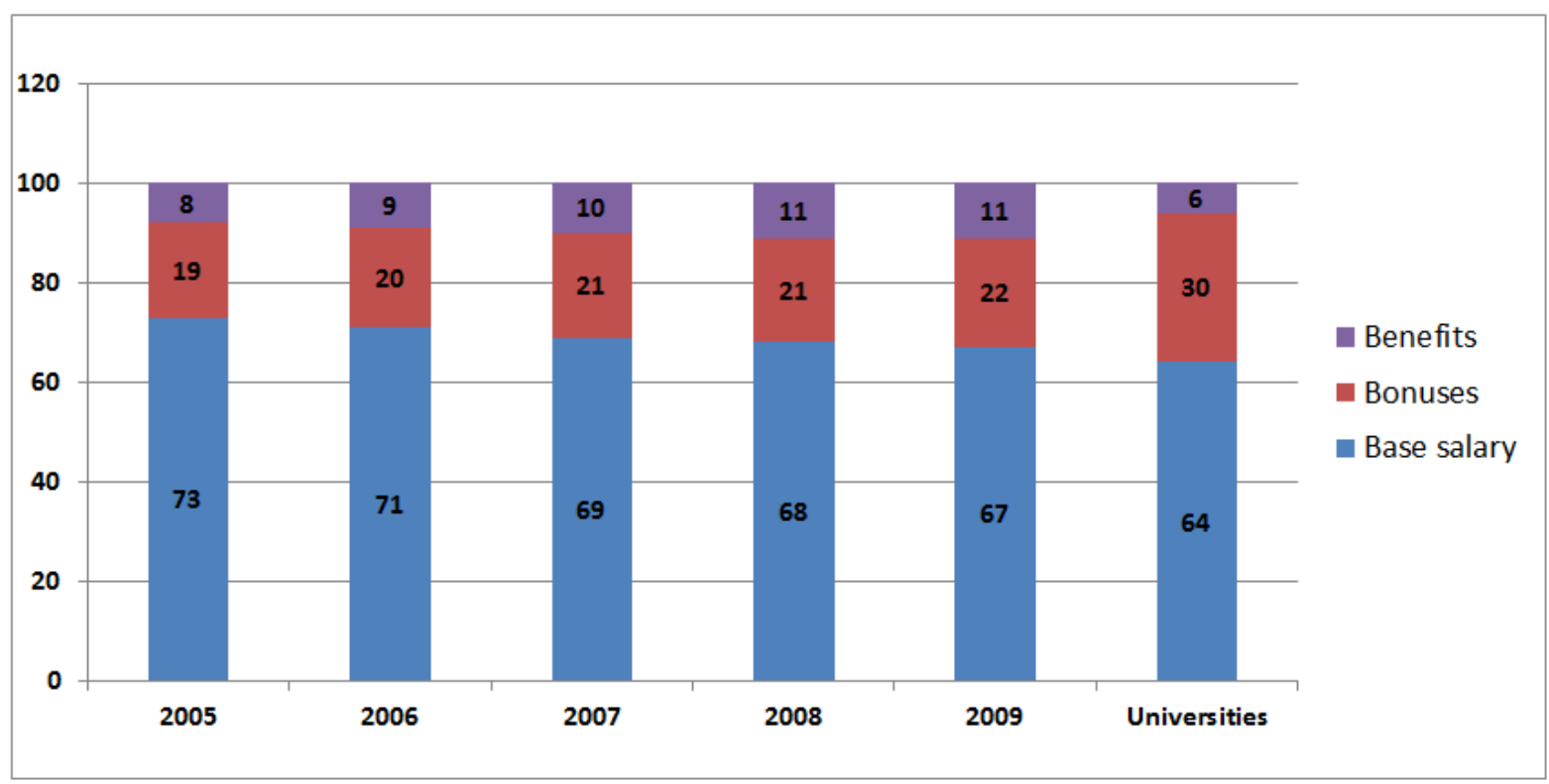

Source: Wage and benefits study of Paywell Romania 2005 - 2009, Pricewaterhouse Coopers

Graph 3: Benefits given to all employees - general market (\% of the participants)

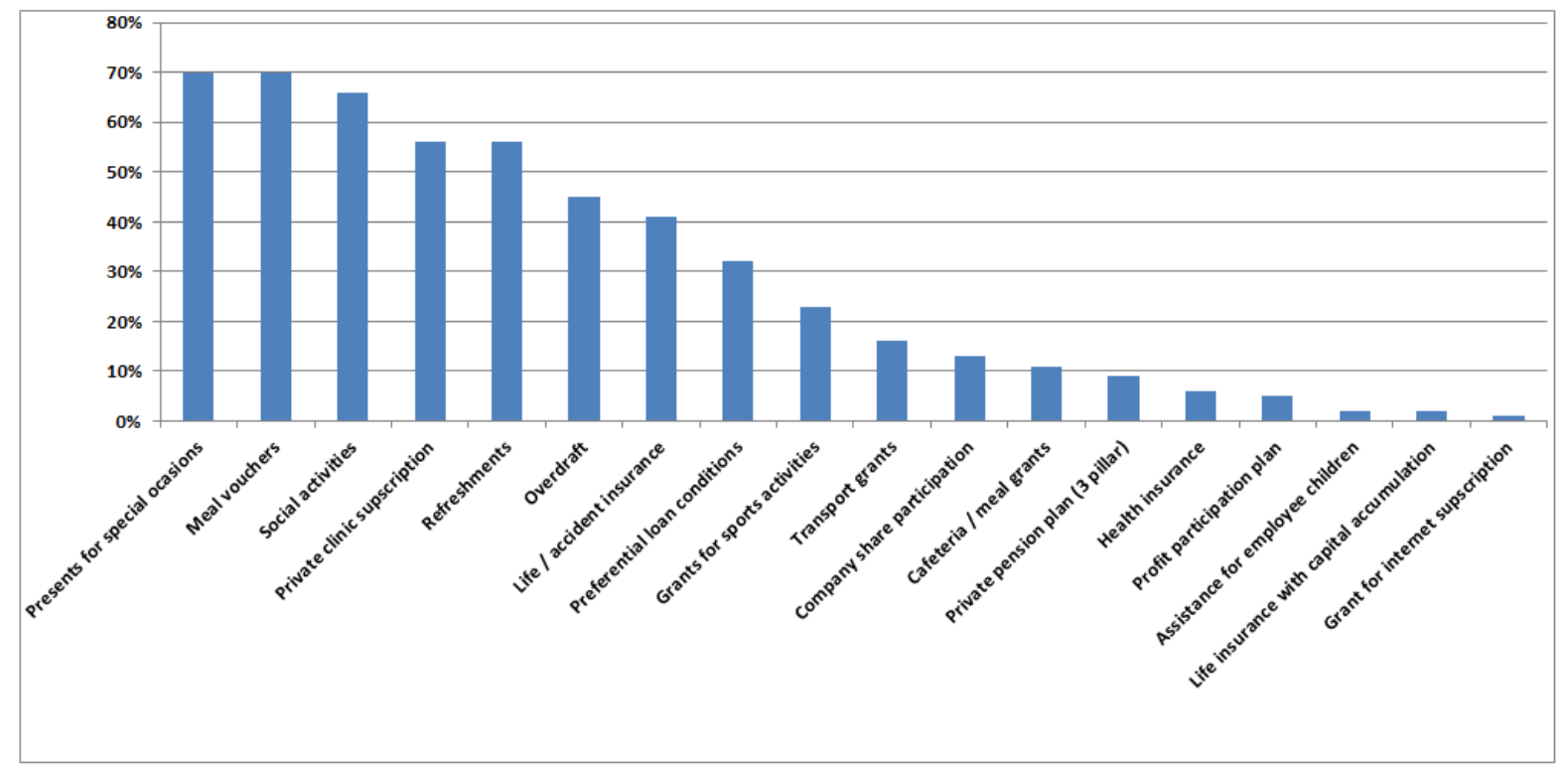

Source: Wage and benefits study of Paywell Romania 2005 - 2009, Pricewaterhouse Coopers

Table 3 illustrating components from the structure of a system of compensation and benefits, presents on column 6 (last column) components that can also be present in the budgetary sector. Column 5 illustrates components of extrinsic motivation which are regulated by law, orange color indicating that for the moment, because of the emergency ordinancy, these components are blocked.

Analyzing this table, we can observe that the retention of employees in public companies is done firstly on the basis of intrinsic motivation, the benefits afferent to this type of motivation being poorly represented. 
Table 3. Differences and possibilities

\begin{tabular}{|c|c|c|c|c|c|c|}
\hline \multirow{17}{*}{ 营 } & \multirow{7}{*}{$\begin{array}{l}\mathrm{I} \\
\mathrm{N} \\
\mathrm{T} \\
\mathrm{R} \\
\mathrm{I} \\
\mathrm{N} \\
\mathrm{S} \\
\mathrm{I} \\
\mathrm{C}\end{array}$} & \multirow{7}{*}{$\begin{array}{l}\text { M } \\
O \\
T \\
\text { I } \\
\text { V } \\
\text { A } \\
T \\
\text { I } \\
\text { O } \\
\text { N }\end{array}$} & \multirow{3}{*}{$\begin{array}{l}\text { Emotional } \\
\text { engagement }\end{array}$} & Company values & & $\mathbf{u}$ \\
\hline & & & & Organizational culture & & $\mathbf{u}$ \\
\hline & & & & Management quality & & $\mathbf{u}$ \\
\hline & & & \multirow{4}{*}{$\begin{array}{l}\text { Engagement } \\
\text { factors }\end{array}$} & Professional development & & $u$ \\
\hline & & & & Personal recognition & & H \\
\hline & & & & Work-personal life balance & & \\
\hline & & & & Team quality - work environment & & $u$ \\
\hline & \multirow{10}{*}{$\begin{array}{l}E \\
X \\
T \\
R \\
\text { I } \\
N \\
S \\
\text { I } \\
C\end{array}$} & \multirow{9}{*}{$\begin{array}{c}\text { M } \\
\text { O } \\
\text { T } \\
\text { I } \\
\text { V } \\
\text { A } \\
\text { T } \\
\text { I } \\
\text { O } \\
\text { N }\end{array}$} & \multirow{3}{*}{$\begin{array}{l}\text { Active } \\
\text { benefits }\end{array}$} & Kindergarten / discount. etc & & \\
\hline & & & & Cafeteria/Accomodation/First relocation & & \\
\hline & & & & Car/Transport/Laptop/Phone & & \\
\hline & & & \multirow{3}{*}{$\begin{array}{l}\text { Passive } \\
\text { benefits }\end{array}$} & Pension, etc & & \\
\hline & & & & Health insurance, etc & & \\
\hline & & & & Days off/Extra leaves & $\mathbf{L}$ & $\mathbf{u}$ \\
\hline & & & \multirow{3}{*}{$\begin{array}{l}\text { Long term } \\
\text { motivation }\end{array}$} & Participation to profit & & \\
\hline & & & & Company shares at preferential price & & \\
\hline & & & & Retention / Lovalty bonuses & & $U / L$ \\
\hline & & & \multirow{4}{*}{$\begin{array}{l}\text { Short term } \\
\text { motivation }\end{array}$} & Meal / Present / Holiday vouchers & $\mathbf{L}$ & $U / L$ \\
\hline \multirow{3}{*}{ 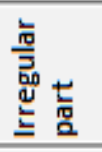 } & & & & Performance bonuses: & & $\mathbf{U} / \mathbf{L}$ \\
\hline & & & & Annual bonuses & $\mathbf{L}$ & $U / L$ \\
\hline & & & & Heliday bonuses & & $\mathbf{U} / \mathbf{L}$ \\
\hline \multirow{3}{*}{ 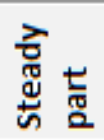 } & & & \multirow{3}{*}{ Cash } & Allowances & $\mathbf{L}$ & $\mathbf{U} / \mathbf{L}$ \\
\hline & & & & Pay rises & $\mathbf{L}$ & $\mathbf{U} / \mathbf{L}$ \\
\hline & & & & Base pay & $\mathbf{L}$ & $\mathbf{U} / \mathbf{L}$ \\
\hline
\end{tabular}

Source: own elaboration

Thus, through the system of compensation and benefits regulated by laws and implemented in the budgetary sector, as well as through the low wage level, as compared to the one existing in the private sector, conditions of a recruitment process and the selection of new specialists with a high level of experience, capable of producing performance in the public sector, are not accomplished.

Consequently, through the system of compensation and benefits rigidly regulated by laws and implemented in the public sector, the short and medium term motivation of employees remains a challenge for managers and for the human resources department from budgetary companies.

This aspect, as well as the low wage level, (compared to that of the private sector) do not ensure the conditions of a recruitment process and the selection of new specialists with a high level of experience, capable of producing performance in public institutions.

We can conclude by stating that the limitations and the rigidity of the legal system which regulates the components present in the structure of the studied system from the public sector do not succeed in ensuring the purpose of a well designed system of compensation and benefits: retaining employees, carrying out a recruitment process and the increase and stimulation of employee individual performances. 


\section{References}

Armstrong, M., \& Taylor, S. (2014). Armstrong's handbook of human resource management practice. Kogan Page Publishers.

Hansen, F. (2006). Currents in compensation and benefits. Compensation \& Benefits Review, 38(5), 6.

Armstrong, M. (2006). Recruitment and Selection: A Handbook of Human Resource Management Practices. Kogan Page, Philadelphia.

Lefter, V., Prejmerean, M., \& Vasilache, S. (2008). The dimensions of organizational intelligence in Romanian companies-a human capital perspective. Theoretical and Applied Economics, 10(10), 39.

Pânzaru, C. (2013). Determinants of International Migration: A Panel Data Analysis, The. J. Pol. \& L., 6, 142.

Pânzaru, C. (2012). The Role of Skills Development in the Local Labour Market, in Larsen, C., Hasberg, R., Schmid, A., Atin, E., Brzozowski, J (eds) Skills Monitoring in European Regions and Localities. Munchen, Mering, pp. 105-114.

\section{Acknowledgments}

This work was co-financed from the European Social Fund through Sectorial Operational Programme Human Resources Development 2007-2013, project POSDRU/187/1.5/S/155559 "Cercetări doctorale multidisciplinare competitive pe plan European."

Această lucrare a beneficiat de suport financiar prin proiectul Cercetări doctorale multidisciplinare competitive pe plan european (CDocMD), contract nr.:POSDRU/187/1.5/S/155559, proiect cofinanţat din Fondul Social European prin Programul Operaţional Sectorial Dezvoltarea Resurselor Umane 2007-2013. 